\title{
Political Parties and Party Organisations
}

Stable parties that successfully perform their representative function and connect to citizens are essential for democratic consolidation (Innes, 2002; Kreuzer \& Pettai, 2004; Markowski, 2011; Tavits, 2013). Whether such parties will form in new European democracies has been questioned from early on (see Mair, 1997), but some degree of democratic stability has been achieved in the new East European EU member states - particularly if we contrast them to most of the Former Soviet Union or Western Balkans. This chapter focuses on the development of political parties in countries that joined the EU in the first two waves; trends elsewhere in other post-communist countries differ considerably because of much lower levels of political stability or political freedoms.

This chapter first looks at types of parties found in the region using a combination of two common approaches: party families and party development. The second section focusses in on the remarkably successful genuinely political parties without clear roots in the transition period and the related phenomenon of major parties suddenly becoming defunct. We then look at the internal life of parties through the analytical lens of party resources: symbiosis with the state, party organisations and membership. The conclusion summarises important trends since early 1990s and critically discusses the relationship between party development and democratic quality.

\section{PARTY TYPES}

Eastern Europe has been rich in the number and variety of political parties; to understand and analyse them, several approaches to party classification have been used. Party families is a classic and generally insightful approach that identifies similar parties across countries (Beyme, 1985; Hloušek \& Kopeček, 2010). However, some parties defy easy classification, some families are internally diverse and parties can even change families. Also, it is not obvious why West European party families should provide a good guide to understanding parties elsewhere. Firstly, even if patterns of party competition in Eastern Europe have come to resemble Western Europe, a unique division communist legacy - remains important in the former (Rohrschneider \& Whitefield, 2013, p.84). Secondly, many East European parties have traits that are at odds with their reference "families" in the West (for a discussion on centre-right see Hanley, 2004); others are programmatically vague or flexible - note the transformation of Fidesz from a liberal to a conservative party (Kiss, 2002).

A related approach to classification is based on parties' membership in European party organisations. Yet, sometimes foes in national politics sit together and close allies in different party groups in the European Parliament. For example, as of 2016, the Czech, Estonian, Lithuanian and Slovak delegations to European People's Party or the Alliance of Liberals and Democrats included parties both from national government and opposition benches.

Three broad groups of parties can be distinguished using a developmental approach: (a) former communists, (b) parties rooted in anti-communist movements, and (c) new parties, usually set up by charismatic leaders. The simple three-fold classification covers most but not all important parties. For example, a small number of parties trace their history back to the pre-communist period - currently significant examples include the Czech Social Democratic Party (ČSSD), the Latvian Farmers' Union (LZS) and the Lithuanian Social Democratic Party (LSDP, now merged with the ex-communist Democratic Labour Party, LDDP). 
1990s saw the astounding reinvention of former communist parties as reformed social democrats. They joined respective party internationals and became central actors in national politics - particularly in Hungary (MSZP), Poland (SLD) and Lithuania (LDDP) (Grzymała-Busse, 2002; Ishiyama, 1997). Former communists are also strong in Bulgaria and Romania (BSP, PSD) where they did not undergo as dramatic a metamorphosis because of the different mode of transition (Grzymała-Busse, 2002; Spirova, 2005).

Initial scholarly interest in ex-communist parties has waned somewhat as predictions about the longterm prospects of SLD and MSZP (Ishiyama 1997) turned out to be premature. SLD became marginalised after 2006 elections and was left out of the Sejm in 2015. MSZP weakened after mass protests following the leaking of its leader's secret speech in 2006; it has remained in the parliament, but in the shadow of Fidesz and its former self. At the time of writing, BSP and PSD as well as the more orthodox Communist Party of Bohemia and Moravia (KSČM) look more stable than successful reformers, bar LDDP

Some communist-era satellites parties have also adapted to democratic party competition, such as the Czech Christian and Democratic Union - Czechoslovak People's Party (KDU-ČSL) and Polish People's Party (PSL). Finally, even where ex-communist parties have all but vanished, some centrist parties have been dominated by former economic or political nomenklatura. Some of them were highly successful in 1990s such as the Estonian Coalition Party (K), its rural sister party People's Union (ERL) and Latvia's Way (LC). The Liberal Democracy of Slovenia (LDS), the dominant party in the country in 1990s, had roots in the former Communist Youth Organisation (Krašovec \& Haughton, 2011, p.200).

The weakening of ex-communist parties in Hungary and Poland coincided with the rise of economically left-leaning but socially conservative parties - Fidesz and Law and Justice (PiS). Both can be linked to former anti-communist movements. Still, most parties with roots in anti-communist movements belong to centre-right mainstream, such as the Czech Civic Democratic Party (ODS), Homeland Union - Lithuanian Christian Democrats (TS-LKD), Slovenian Democratic Party (SDS) and Estonian Pro Patria Union (IL). In Poland, both PiS and the more liberal Citizens' Platform (PO) have roots in Solidarity alliance that became a victim of its descendants' success in 2001 and has since turned back into a trade union.

Successful ethno-nationalist radical right parties, largely overlapping with "populist radical right" (Mudde, 2007), have been a concern for the prospects of liberal democracy and have received ample scholarly attention. Some of them have roots in anti-communist movements - e.g. the League of Polish Families (LPR), the Latvian National Alliance (NA) - while others have tenuous links, e.g. Jobbik (Hungary), Ataka (Bulgaria), Greater Romania Party (PRM), Dawn (Czech Republic), the Slovak National Party (SNS), People's Party - Our Slovakia (LSNS) and the Estonian Conservative People's Party (EKRE).

Ethno-nationalist radicals have won modest representation in the parliament - in 2016, they held 1020 percent of seats only in Slovakia, Latvia and Hungary. Few have been popular over several years, entered national government or influenced them directly (Minkenberg, 2007, p.36). More worryingly, they have encouraged radical rhetoric among mainstream parties, particularly in Hungary and Slovakia (Pirro, 2015). Ethno-nationalist right has often been strong in countries with prominent ethnic minorities (Bulgaria, Slovakia and Latvia), but also in ethnically rather homogenous Hungary and Poland. On the other hand, ethno-nationalist right was absent from the Estonian parliament 19992015 despite a sizeable Russian-speaking minority in the country. 
Radical right can benefit from the presence of strong ethnic minority parties, particularly if they enter the government (Bustikova-Siroky, 2013). Various incarnations have been in strong in Latvia, where the Harmony Centre (SC) became the largest party in 2011. Minority parties have also been strong in Romania (the Democratic Union of Hungarians, UDMR), Bulgaria (Movement for Rights and Freedom, DPS) and Lithuania (the Electoral Action of Poles). The latter two have at times also been included in national governments. No ethnic minority party has been represented in the Estonian parliament since 1999 as the predominantly ethnic Estonian Centre Party (KE) with roots in the moderate wing of the independence movement has achieved a near-monopoly of ethnic Russian representation. In contrast, in Slovakia, the mostly ethnic Hungarian Most-Híd has recruited Slovak candidates and drove the more traditional Party of the Hungarian Community out of the parliament in 2010 .

\section{PARTIES: NEW AND OLD}

East European parties, except for pre-communist and communist successor parties, are new compared to nearly all parties in Western democracies. However, a crucial distinction can be made between those with roots in late communist or early post-communist years and those lacking such connections, for example at the level of senior personnel. The continued success of the former has generally contributed to the institutionalisation of the party system established in early 1990s, while the latter some of which were already discussed at the end of previous section - have often disrupted the fragile equilibrium.

Tracing the development of parties poses problems. In the first parliaments, broad movements split up as other issues than communist/anti-communist dimension took precendence - largely a natural development reflecting changes in political and social conditions. This disintegration was often followed by some consolidation in the form of mergers (e.g. the setting up of Solidarity Electoral Action, AWS in Poland) and disappearance of minor parties, but also by further splits and other forms of reorganisation. The transformations have often been complex, involving several parties or alliances exchanging political personnel in various directions.

Telling old and new parties apart is complicated as: (a) there have been considerably more electoral coalitions - that can obscure their constituent parties - than in Western Europe (Ibenskas, 2015; Marinova, 2015) and (b) many seemingly new formations have been strongly related to previously existing ones.

Coalitions were common in early post-communist elections, but have remained prominent in Latvia, Lithuania, Poland and Romania. In 2010 Latvian parliamentary elections, all six "electons" - to use a common name for parties and coalitions (Sikk, 2013) - winning seats were electoral coalitions. Some countries have discouraged coalitions by setting them higher electoral thresholds (Lithuania, Poland) or prohibiting them in parliamentary elections (Estonia). Such measures were introduced to prevent (temporary) coalitions that can slow down party system consolidation by helping parties to enter parliament without ensuring cooperation later. However, some coalitions have endured over a number of elections and developed permanent organisational links, e.g. Fidesz and Christian Democratic People's Party (KDNP) in Hungary (since 2006) and the Union of Greens and Farmers in Latvia (ZZS, since 2002). Some electoral coalitions have transformed into proper parties, e.g. Unity (Vienotiba) after winning 2010 elections in Latvia. Yet other coalitions have been pragmatic and short-lived, particularly those in Romania or involving the Lithuanian LSDP. 
Coalitions, splits and mergers make identifying new political parties difficult. An important distinction regards parties set up by leading figures of established parties and those with weak or no links to existing party politics. Such genuinely new parties (Sikk, 2005) have often been remarkably successful (see Table 1) - six of their leaders became prime ministers after their first election (LS, JL, NDSV, PMC, RP, GERB). To these we can add: (a) parties that won the biggest number of votes but did not form a government (PS and DP), (b) Smer (Slovakia) that became truly successful only in its second election and (c) the Latvian People's Party (TP), created by a former independent Prime Minister who occupied the office soon again. Some genuinely new parties have been radical right populists (Jobbik, PRM) or more vaguely populist (Polish Self-Defence, Lithuanian TPP and DP). Others have been post-materialist with an East European flavour (the Greens in Czechia and Estonia), anti-political promoting electoral reform (Kukiz in Poland) or single-issue parties (the Lithuanian Way of Courage promised to tackle a supposed paedophile ring).

Table 1 Genuinely new parties $(\mathrm{V}>15 \%)$

\begin{tabular}{|c|c|c|c|c|c|}
\hline Party & Country & $\begin{array}{r}\text { First } \\
\text { election }\end{array}$ & Votes \% & Leader & $\begin{array}{r}\text { Political office } \\
\text { after election }\end{array}$ \\
\hline Citizens for European Development (GERB) & Bulgaria & 2009 & 39.7 & Boyko Borisov & PM \\
\hline Positive Slovenia (PS) & Slovenia & 2011 & 28.5 & Zoran Janković & - \\
\hline Labour Party (DP) & Lithuania & 2004 & 28.4 & Viktor Uspaskich & - \\
\hline Res Publica (RP) & Estonia & 2003 & 24.6 & Juhan Parts & PM \\
\hline New Union (Social Liberals) (NS-SL) & Lithuania & 2000 & 19.6 & Artūras Paulauskas & Speaker \\
\hline ANO2011 & Czechia & 2013 & 18.7 & Andrej Babiš & Minister of Finance \\
\hline Liberal Union (LLS) ${ }^{a}$ & Lithuania & 2000 & 17.3 & Rolandas Paksas & PM \\
\hline Jobbik & Hungary & 2010 & 16.7 & Dávid Kovács & - \\
\hline TOP 09 & Czechia & 2010 & 16.7 & rel Schwarzenberg & Minister of Foreign Affairs \\
\hline
\end{tabular}

All genuinely new parties have used some "populist" anti-establishment rhetoric, easily explained by their outsider status. However, the most successful ones (nearly all in Table 1) have had a centrist or liberal outlook and have been dubbed "centrist populists" or "unorthodox parties" (Učeň, 2007; PopEleches, 2010). Often, they have fought on an ideological territory of established parties, mostly distinguishing themselves by "newness" (Sikk, 2011) - a combination of charisma, projected integrity, and competence, sometimes combined with calls for democratic reforms (Hanley \& Sikk, 2013). A mainstream, catch-all appeal has been a crucial factor behind their success - even if extremist parties in general outperform centrists (see Ezrow et al., 2014 whose data includes only one party from Table 1). Such anti-establishment reform parties have been successful both in economic good and bad times, but benefit from rising levels of perceived corruption in relatively less corrupt countries (Hanley \& Sikk, 2013). Notably, mainstream genuinely new parties have been conspicuous by their absence in Romania where corruption has been highest among the countries covered in this chapter until recently.

Figure 1 shows the distribution of seats won by genuinely new parties in elections by countries. Their average success has been lowest in Hungary and Romania and highest in Bulgaria, Slovenia and Lithuania. There is significant within-country variation - nearly all countries have had elections where genuinely new parties won no seats and elections where they have been highly successful, reaching near-majority twice in Bulgaria. Figure 2 shows no overall trend over time, but genuinely new parties have become more successful in two periods: (a) between 2000 and 2005, shortly before or after the countries joined the EU and (b) since 2010, Czechia and Slovenia - with previously stable party systems - experienced two consecutive elections with high levels of genuinely new party success. 
Most of the successful new parties have burned out quickly. NDSV, PS, ZRP, NS-SL and TPP saw their popularity plummet almost immediately after their initial success. LLS, RP and JL lost independent existence following mergers with older parties, but many of their leaders continue in national politics. Of the parties listed in Table 1, only DP managed to survive more than a decade in its original form, albeit obtaining a new legal identity to avoid charges of fraudulent funding. By 2016, some newer parties (GERB, ANO2011, TOP09) had retained considerable support or increased it (Jobbik).

Figure 1 Genuinely new parties in elections (by countries)

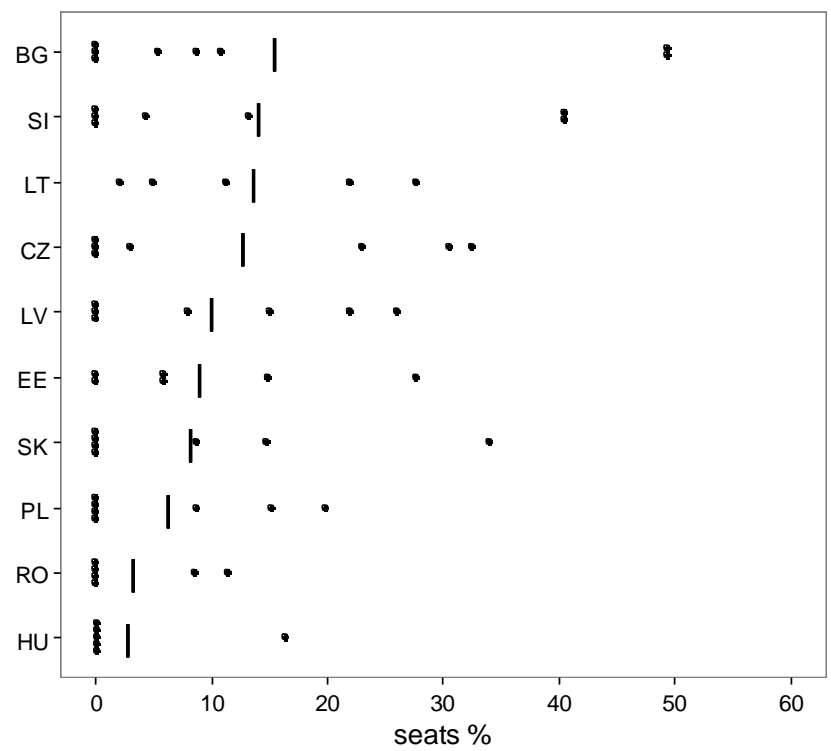

Note: Horizontal dashes show average share of seats won by genuinely new parties. Source: Author's calculations. Data: allansikk.eu/HBEEP

Figure 2 Trends of genuinely new party success
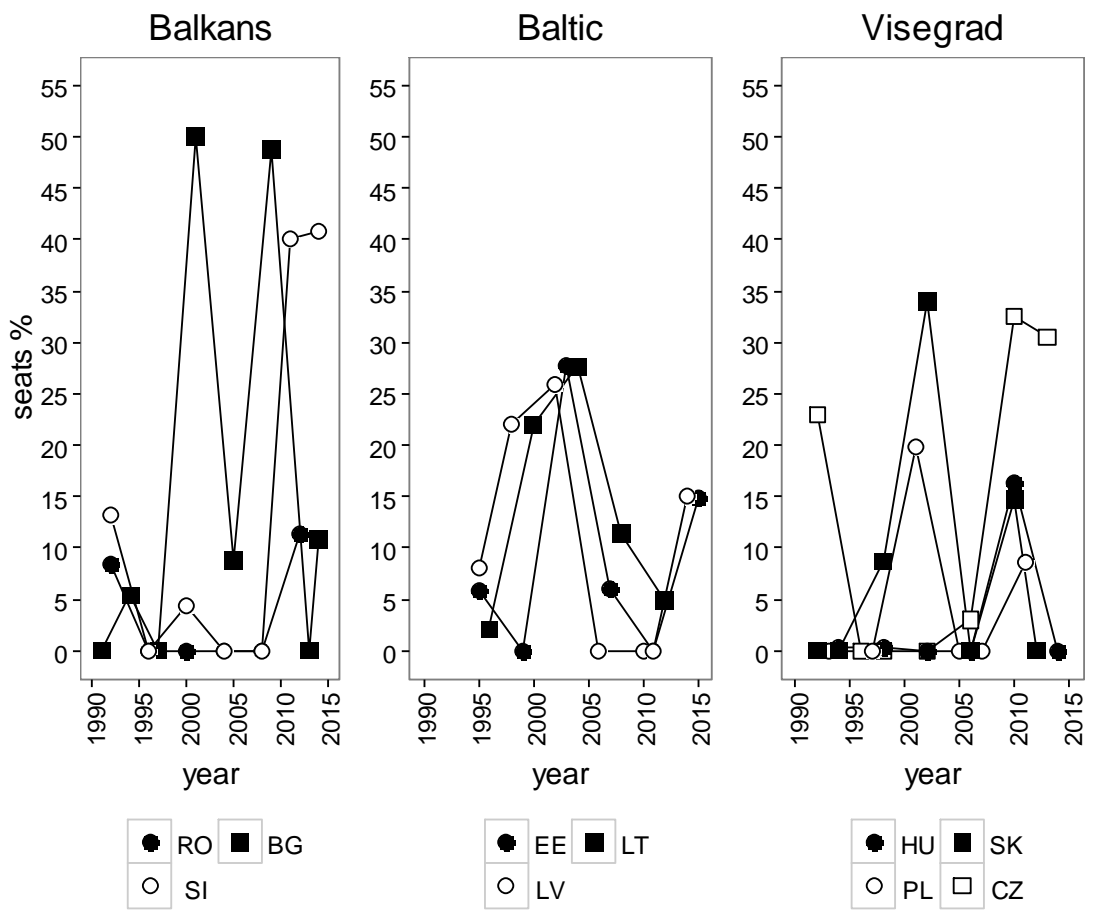

Source: Author's calculations. Data: allansikk.eu/HBEEP 
In parallel with the breakthroughs of genuinely new parties, several parties that dominated political systems in 1990s have disappeared without leaving easily identifiable descendants. Eight parties leading governments for years were no longer in the parliament or existence by 2016: AWS and SLD (Poland); K (Estonia), LC and TP (Latvia); People's Party - Movement for a Democratic Slovakia (HZDS) and Slovak Democratic and Christian Union - Democratic Party (SDKÚ-DS); and LDS (Slovenia). Other key parties from 1990s and 2000s have been severely weakened, e.g. ODS in Czechia and MSZP in Hungary. However, such "party death" may not be as tragic as the term implies. A party may have simply achieved its core aims, e.g. parties whose raison d'être was defeating communism were redundant once it was achieved. Parties can also liquidate if the objectives of their leaders or patrons have been achieved, e.g. favourable laws passed or personal fortunes amassed. Either way, leaders of defunct parties may still (happily!) continue in politics or (possibly more happily!) enjoy political retirement as wealthy businesspeople. Obviously, for some parties, disappearance may be tragic and it is empirically difficult to test the "achievement of aims" hypothesis, even though parties often decay following scandals and many former leaders of defunct parties did become wealthy following their spell in government. This could mean that some parties or leaders may be motivated less by the prospect of re-election but try to achieve as much as possible while in power, regardless of political costs (Sikk, 2006: 154-56). If so, such "disposable" parties undermine a core principle of electoral (retrospective) accountability, particularly as they set examples for other political entrepreneurs. Finally, persistence and change can also go together despite the instability of the Lithuanian party system, the two parties (TS-LKD and LSDP) that dominated almost all governments in the 25 years after the fall of communism, remained the largest parliamentary parties in 2016.

\section{PARTY ORGANISATION}

In order to perform their essential functions properly, parties need at least some form of organisation. They need to coordinate activities between different fora, such as the government, the parliament, regional and local politics, members, candidates and voters, and reach different voters and regions in a country. East European parties have been diverse in terms of their organisation and eager to innovate around classical models of party organisation. In particular, they have been skilfully substituting traditional partisan resources of membership and organisational structure by others such as money, visible leaders or easily digestible campaign messages.

Parties' organisational features can partly be linked to their developmental paths. For example, despite limited electoral appeal, the Czech communist successor party KSČM has retained one of the biggest membership organisations in the region (Linek \& Pecháček, 2007). Recent studies have shown that party organisation and membership base can be beneficial for parties' electoral success (Tavits, 2013; Ibenskas, 2014), still offering limited protection against subsequent failures (Hanley, 2015).

Even if membership organisations have benefitted some parties, the parties in the region are very diverse. In contrast, genuinely new parties have often been set up by political entrepreneurs with easy access to money for marketing to compensate for a lack of a proper organisation (at least initially). Parties broadly emulating the "business firm" model of Silvio Berlusconi's Forza Italia (Hopkin \& Paolucci, 1999) have been common in Central and Eastern Europe - e.g. the Czech ANO2011 and Lithuanian DP with a degree of fusion between party organisation and its leader's business (Tomšič \& Prijon, 2013; Olteanu \& Nève, 2014).

Other resources that have compensated for rudimentary organisation are easy-to-digest "populist" messages and charismatic and prominent leadership. Many new parties have very weak organisations 
simply because they have often been created very shortly before elections - as little as six (SMC) or eleven (NDSV) weeks prior. Brand-new parties with only a handful of members can have advantages - competitors and the media have less time to discover or invent skeletons in cupboards and leaders face little internal pressures from members. For such parties (also in Western Europe) membership and organisation matter relatively little, certainly in terms of initial success. Still, organisational weakness has been a key reason why most of the genuinely new parties have fizzled out fast. Those more successful over time - e.g. Smer, JL (later transformed into Unity), DP and GERB - have usually went on to develop more intricate organisations.

Another important development has been the growing symbiosis of political parties and the state (Kopecký, 2006). All countries have introduced direct public funding to political parties, finally in Latvia in 2010 (Biezen \& Kopecký, 2014). Established "resource-poor and power-hungry" parties, in particular, have benefitted from increased public funding in addition to resources provided by party patronage when in power (Kopecký \& Spirova, 2011, p.897; Kopecký et al., 2012). Financial dependence on public funding is notably higher among East European parties compared to most of their West European counterparts. The availability of public funding for political parties has lowered incentives for parties to seek resources (financial and otherwise) elsewhere by developing strong membership organisation and links with the rest of the society (ibid, p.171). Public subsidies have also helped benefitting parties to survive even following electoral backlashes (e.g. in Poland, see Casal Bértoa \& Walecki, 2014). Still, genuinely new party successes show that cartelisation at the level party system has been limited. The combination of a privileged status and policy space constrained by Europeanisation/globalisation space (Blyth \& Katz, 2005) has made established parties complacent, blaming forces beyond their control for unpopular or ineffective policies. Ironically, that has partly helped to prepare ground for electoral earthquakes by anti-establishment reform parties.

Levels of party membership have been falling in Eastern Europe, in line with the trends in the West, albeit from a lower starting point. Van Biezen et al (2012) report that party membership remains below the European average except in Bulgaria, Estonia and Romania. In the decade until late 2000s, it dropped everywhere by 25 percent or more, except in Estonia and Poland (ibid, p. 32). Some countries have established rather stringent membership requirements - particularly Romania and Slovakia where respectively 25,000 and 10,000 founding members are required for registration. In contrast, fewer than 50 founding members are required in Bulgaria, Hungary and Poland (Cabada et al., 2014: 108-9). Such requirements are not necessarily reflected in overall party membership levels, e.g. it remains low in Slovakia. While required membership is medium in Estonia $(1,000,500$ from 2014), the membership lists are public. To protect themselves against defections, parties usually maintain a healthy surplus of members as only officially registered parties can contest parliamentary elections.

Figure 3 shows trends in party membership and identification based on European Social Survey until 2010 (when a question on party membership was last included). It shows notable decreases in membership almost everywhere. Countries with higher levels of membership have also seen a notable drop in party identification between 2008 and 2010, particularly pronounced in Slovenia and Czechia that experienced party system ruptures in that period. 
Figure 3 Trends in party identification and party membership

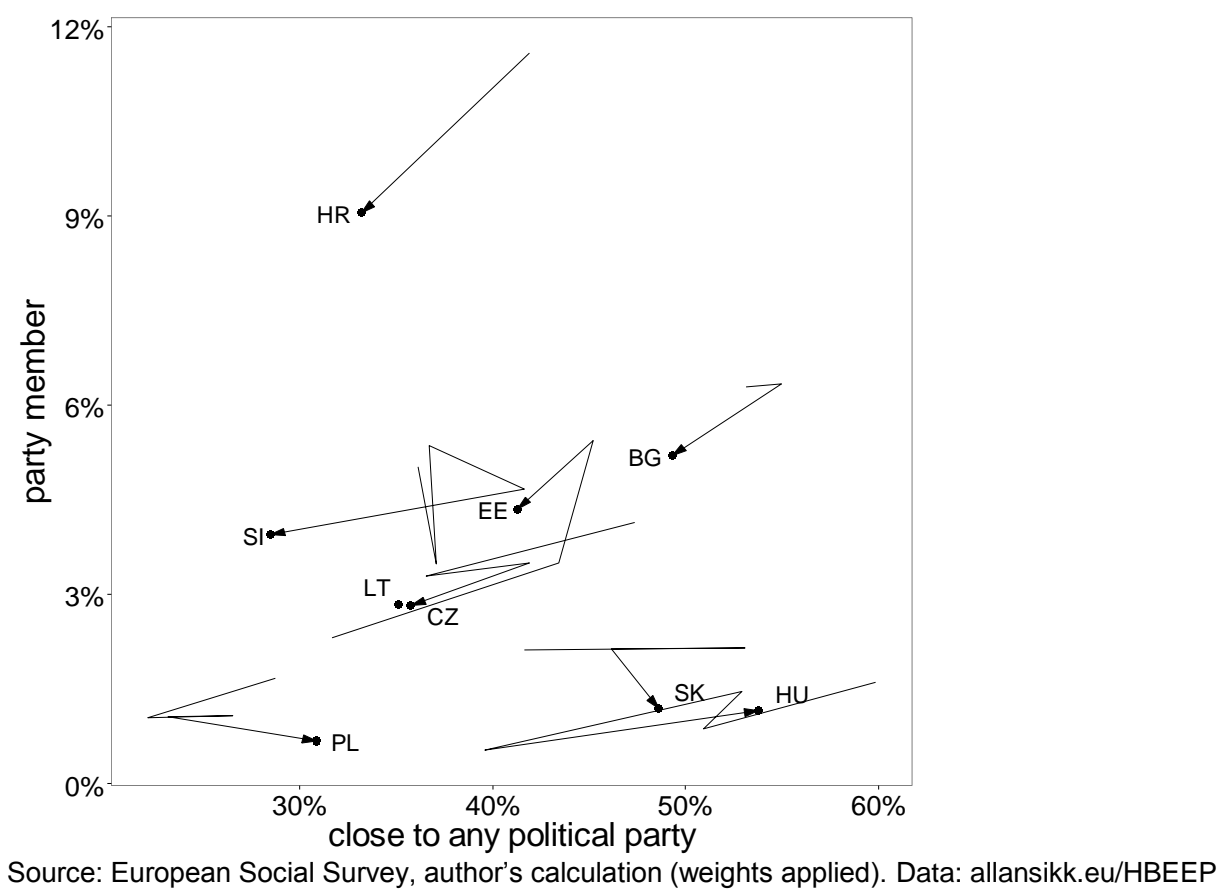

Figure 4 shows that voters' attachment to parties is generally very weak. Strong identification is strikingly low in Estonia and Slovenia despite relatively high membership levels - even many members do not feel "very close" to their parties. On the other hand, closeness is substantially stronger than party membership in countries with low membership levels, particularly in Hungary. Only Bulgaria has both high levels of identification and membership. Hence, one should be careful with interpreting survey-based membership figures (although perhaps more reliable than figures reported by parties) as an indicator of strength between parties and the society at large. Links can be relatively strong where membership is relatively low and vice versa.

Also, stronger party identification does not necessarily bode well for democracy - Hungary and Bulgaria have recently experienced democratic setbacks. Strong identification might not be conducive for liberal democracy if it is the effect of parties that are over-institutionalised, personalistic, heavily involved in patronage or cultivating clientelist linkages. Such linkages may promote electoral stability (Gherghina, 2014), but could in the longer run be even more dangerous for the quality of democracy than political fragmentation or party system dynamism (Enyedi, 2016; Gurov \& Zankina, 2013; Schedler, 1995). Finally, large membership and forms of active engagement (e.g. internal ballots) that link leadership directly to individual members may in fact be a form of elite control. Genuine intraparty democracy entails development of mid-level structures to promote deliberation and act as an incubator for alternative leadership (Enyedi, 2014). For that, large membership may not necessarily be required given the pan-European tendency away from amateur politicians and politics becoming a profession rather than a vocation (Biezen \& Poguntke, 2014). 


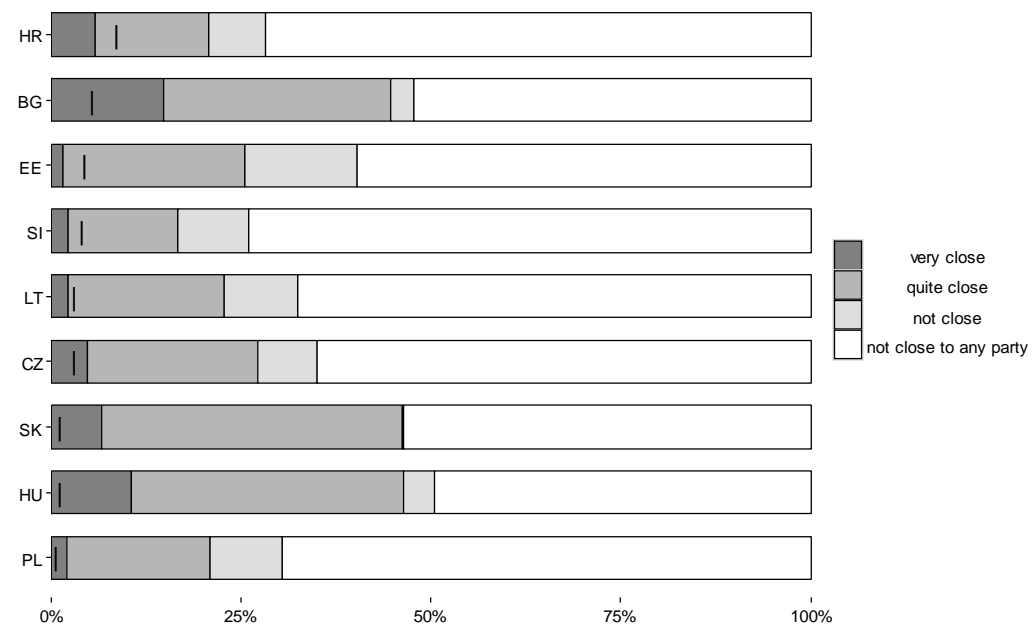

Note: Dashes show the overall level of party membership. Those in the first three categories reported some closeness to a political party ("not close at all" combined with "not close").

Source: European Social Survey, Round 5, author's calculations (weighted).

Data: allansikk.eu/HBEEP

Our understanding of how political parties work and how it is linked to party system stability, electoral volatility and democratic quality has until recently been constrained by limitations of comparative data. Recently, more data spanning space and time has been collated. One major new direction in party studies is the extant research on party regulation. The region has been characterised by restrictions on party registration (deposits, membership requirements and ideological limitations), yet limited regulations on internal party affairs; considerable state subsidies, yet light oversight of party finances (Casal Bértoa \& van Biezen, 2014). However, the effects and determinants of party regulation need further research based on the accumulated data. Another extant stream of literature focuses on electoral candidates that can be seen as a link between parties as membership and electoral organisations. Thanks to greater availability of data, new insights have been gained about campaigns and district-level spending (Trumm, 2015, based on Comparative Candidates Survey), the role of parties in inhibiting female representation (Allik, 2015) as well as general patterns of candidate change as an key aspect of party change (Sikk \& Köker, 2015).

\section{CONCLUSION}

Representative democracy needs institutionalised parties and party systems, but there are only limited signs of either in Eastern Europe. Excessive change and fragmentation makes it more difficult for voters are to understand the available electoral options and for parties to coordinate legislative and executive activities. Nearly all countries discussed in this chapter have seen breakthroughs by often vaguely defined but extremely popular new parties with no roots in previously existing political parties. It looks likely that political parties and party systems here (but also in West Europe, e.g. Spain, Greece, Italy, Austria, Germany, Netherlands) are converging towards a new equilibrium of party politics where new parties are frequent and innovative (not necessarily in a positive sense) in their ideological profiles and organisational features (e.g. memberless parties, see Mazzoleni \& Voerman, 2016).

Many argue that stable parties are necessary - but not sufficient - for the quality of democracy (Mainwaring, 1999; Casal Bértoa, 2014); yet even stability itself cannot be the sole aim. Some stability in parties is necessary for accountability, responsiveness and quality of representation, but 
democratic party systems need to be open so that new parties can reflect social changes and "underperforming" parties could be replaced by prophets and purifies, respectively (Lucardie, 2000).

Perhaps the most striking observation when comparing earlier literature on party consolidation with more recent developments how premature many of the predictions in literature were regarding institutionalisation. Electoral ruptures have occurred in the face of seeming stability that might have been stagnation in disguise - e.g. the recent the double earthquakes in Czechia and Slovenia or the downfall of the former communist parties in Hungary and Poland. Yet, there is little evidence that instability poses the worst problem for democracy - if anything, the recent political dominance of conservative forces in Poland and Hungary seems to be more problematic, echoing Anna GrzymałaBusse's arguments about the importance of healthy party completion for preventing excessive state capture (2007). It is worth keeping in mind that institutionalized parties and party systems may or may not be consolidated democracies. (Hicken \& Martinez Kuhonta, 2011) .

From a normative point of view one may nostalgically lament that the "golden age" of West European party politics (that probably never was, see Webb, 2002, p.11) has not reached Eastern Europe. The odds were always against it as the region democratised in an era of "post-modern" politics (Kitschelt et al., 1999) where the context of party formation led them to resemble contemporary parties in the older democracies (Biezen, 2005) or even leap-frog them. Can democracy survive or thrive in the new era of party politics? It could be difficult, but civil society, domestic interests and international actors must strive to make the unstable kind of party politics serve the quality of democracy as best as it can. Alternatives - such as stable mass-membership parties with clear ideological profiles based on "frozen" conflict dimensions, backed up by voters with strong partisan attachments - may no longer be possible in Central and Eastern Europe or elsewhere, as Western Europe is experiencing deinstitutionalisation, too (Chiaramonte \& Emanuele, 2015).

\section{BIBLIOGRAPHY}

Allik, M. (2015) Who stands in the way of women? Open vs. closed lists and candidate gender in Estonia. East European Politics, 31 (4), pp.429-451.

Beyme, K. von (1985) Political Parties in Western Democracies. Aldershot, Gower.

Biezen, I. v. \& Poguntke, T. (2014) The decline of membership-based politics. Party Politics, 20 (2), pp.205216.

Biezen, I. van (2005) On the theory and practice of party formation and. European Journal of Political Research, pp.147-174.

Biezen, I. van \& Kopecký, P. (2014) The cartel party and the state: Party-state linkages in European democracies. Party Politics, 20 (2), pp.170-182.

Biezen, I. van, Mair, P. \& Poguntke, T. (2012) Going, going , . . gone ? The decline of party membership in. European Journal of Political Research, 51 (1), pp.24-56.

Blyth, M. \& Katz, R. (2005) From Catch-all Politics to Cartelisation: The Political Economy of the Cartel Party. West European Politics, 28 (1), pp.33-60.

Bustikova-Siroky, L. (2013) Revenge of the Radical Right. 2nd European Conference in Comparative Electoral Research, 47 (August), pp.1-33.

Cabada, L., Hloušek, V. \& Jurek, P. (2014) Party Systems in East Central Europe. Lanham, MD., Lexington Books.

Casal Bértoa, F. (2014) Party systems and cleavage structures revisited: A sociological explanation of party 
system institutionalization in East Central Europe. Party Politics, 20 (1), pp.16-36.

Casal Bértoa, F. \& van Biezen, I. (2014) Party regulation and party politics in post-communist Europe. East European Politics, 30 (3), pp.295-314.

Casal Bértoa, F. \& Walecki, M. (2014) Regulating Polish politics: 'cartel' parties in a non-collusive party system. East European Politics, 30 (3), pp.330-350.

Chiaramonte, A. \& Emanuele, V. (2015) Party system volatility, regeneration and de-institutionalization in Western Europe (1945-2015). Party Politics, (Published online before print August 25, 2015).

Enyedi, Z. (2016) Populist Polarization and Party System Institutionalization. Problems of Post-Communism, p.Published online: 14 Jan 2016.

Enyedi, Z. (2014) The discreet charm of political parties. Party Politics, 20 (2), pp.194-204.

Ezrow, L., Homola, J. \& Tavits, M. (2014) When Extremism Pays: Policy Positions, Voter Certainty, and Party Support in Postcommunist Europe. Journal of Politics, 76 (2), pp.1-13.

Gherghina, S. (2014) Party organization and electoral volatility in Central and Eastern Europe: enhancing voter loyalty. Oxon, Routledge.

Grzymała-Busse, A.M. (2007) Rebuilding Leviathan. Party competition and state exploitation in postcommunist democracies.

Grzymała-Busse, A.M. (2002) Redeeming the Communist Past: The Regeneration of Communist Parties in East Central Europe. Cambridge, Cambridge University Press.

Gurov, B. \& Zankina, E. (2013) Populism and the Construction of Political Charisma Post-Transition Politics in Bulgaria. Problems of Post-Communism, 60 (1), pp.3-17.

Hanley, S. (2015) All Fall Down? The Prospects for Established Parties in Europe and Beyond. Government and Opposition, 50 (02), pp.1-24.

Hanley, S. (2004) Getting the right right: redefining the centre-right in post-communist Europe. Journal of Communist Studies and Transition Politics, 20 (3), pp.9-27.

Hanley, S. \& Sikk, A. (2013) Economy, corruption or promiscuous voters? Explaining the success of AntiEstablishment Reform Parties in Eastern Europe. Party Politics, (July), pp.1-41.

Hicken, a. \& Martinez Kuhonta, E. (2011) Shadows From the Past: Party System Institutionalization in Asia. Comparative Political Studies, 44 (5), pp.572-597.

Hloušek, V. \& Kopeček, L. (2010) Origin, Ideology and Transformation of Political Parties. Farnham, Ashgate.

Hopkin, J. \& Paolucci, C. (1999) The Business Firm Model of Party Organisation: Cases from Spain and Italy. European Journal of Political Research, 35 (3), pp.307-339.

Ibenskas, R. (2014) Activists or money? Explaining the electoral success and persistence of political parties in Lithuania. Party Politics, 20 (6), pp.879-889.

Ibenskas, R. (2015) Understanding Pre-Electoral Coalitions in Central and Eastern Europe. British Journal of Political Science, (Published online before print), pp.1-19.

Innes, A. (2002) Party Competition in Postcommunist Europe: The Great Electoral Lottery. Comparative Politics, 35 (1), pp.85-104.

Ishiyama, J.T. (1997) The Sickle or the Rose?: Previous Regime Types and the Evolution of the Ex-Communist Parties in Post-Communist Politics. Comparative Political Studies, 30 (3), pp.299-330.

Kiss, C. (2002) From Liberalism to Conservatism: The Federation of Young Democrats in Post-Communist Hungary. East European Politics \& Societies, 16 (3), pp.739-763. 
Kitschelt, H., Mansfeldova, Z., Markowski, R. \& Toka, G. (1999) Post-Communist Party Systems. Competition, Representation, and Inter-Party Cooperation. Cambridge, Cambridge University Press.

Kopecký, P. (2006) Political parties and the state in post-communist Europe: The nature of symbiosis. Journal of Communist Studies and Transition Politics, 22 (3), pp.251-273.

Kopecký, P., Mair, P. \& Spirova, M. (2012) Party patronage and party government: Public appointments and political control in European democracies. Oxford, Oxford University Press.

Kopecký, P. \& Spirova, M. (2011) 'Jobs for the Boys'? Patterns of Party Patronage in Post-Communist Europe. West European Politics, 34 (February), pp.897-921.

Krašovec, A. \& Haughton, T. (2011) Money, organization and the state: The partial cartelization of party politics in Slovenia. Communist and Post-Communist Studies, 44 (3), pp.199-209.

Kreuzer, M. \& Pettai, V. (2004) Political Parties and the Study of Political Employmnet: New Insights from the Postcommunist Democracies. World Politics, 56, pp.608-633.

Linek, L. \& Pecháček, Š. (2007) Low Membership in Czech Political Parties: Party Strategy or Structural Determinants? Journal of Communist Studies and Transition Politics, 23 (2), pp.259-275.

Lucardie, P. (2000) Prophets, Purifiers and Prolocutors: Towards a Theory on the Emergence of New Parties. Party Politics, 6 (2), pp.175-185.

Mainwaring, S. (1999) Rethinking Party Systems in the Third Wave of Democratization: The Case of Brazil. Stanford, CA, Stanford University Press.

Mair, P. (1997) Party System: Approaches and Interpretations. Oxford University Press.

Marinova, D.M. (2015) A New Approach to Estimating Electoral Instability in Parties. Political Science Research and Methods, 3 (2), pp.265-280.

Markowski, R. (2011) The Quality of Democracy in Eastern Europe. Public Preferences and Policy Reforms. West European Politics, 34, pp.1323-1325.

Mazzoleni, O. \& Voerman, G. (2016) Memberless parties: Beyond the business-firm party model? Party Politics, (published online before print).

Minkenberg, M. (2007) Transforming the Transformation?: The East European Radical Right in the Political Process. Oxon, Routledge.

Mudde, C. (2007) Popoulist Radical Right Parties in Europe. Cambridge University Press.

Olteanu, T. \& Nève, D. de (2014) Business Firm or rather Business Men Parties? In: IPSA/AISP 23rd World Congress of Political Science, Montréal.

Pirro, A. (2015) The Populist Radical Right in Central and Eastern Europe: Ideology, Impact, and Electoral Performance. Oxon, Routledge.

Pop-Eleches, G. (2010) Throwing out the bums: Protest voting and unorthodox parties after communism. World Politics, 62 (2), pp.221-260.

Rohrschneider, R. \& Whitefield, S. (2013) The Strain of Representation: How Parties Represent Diverse Voters in Western and Eastern Europe. Oxford, Oxford University Press.

Schedler, A. (1995) Under and Overinstitutionalization: Some Ideal Typical Propositions Concerning new and old party systems.

Sikk, A. (2013) Electoral Congruence and Novelty: Accounting for Partially New Parties. In: ECPR Join Sessions of Workshops. Mainz.

Sikk, A. (2006) Highways to power: new party success in three young democracies. Tartu, Tartu University Press. 
Sikk, A. (2005) How unstable? Volatility and the genuinely new parties in Eastern Europe. European Journal of Political Research, 44 (3), pp.391-412.

Sikk, A. (2011) Newness as a winning formula for new political Parties. Party Politics, 18 (4), pp.465-486.

Sikk, A. \& Köker, P. (2015) Candidate Turnover and Party System Change in Central and Eastern Europe. In: ECPR General Conference. Montreal.

Spirova, M. (2005) Political parties in Bulgaria - Organizational trends in comparative perspective. Party Politics, 11 (5), pp.601-622.

Tavits, M. (2013) Post-Communist Democracies and Party Organization. Cambridge University Press.

Tomšič, M. \& Prijon, L. (2013) Person-based politics in Italy and Slovenia: Comparing cases of leadership's individualisation. International Social Science Journal, 64 (213-214), pp.237-248.

Trumm, S. (2015) What Does It Take to Get Elected in a Post-Communist Democracy?: Explaining the Success and Failure of Parliamentary Candidates in Estonia. East European Politics \& Societies, 30 (1), pp.169188.

Učeň, P. (2007) Parties, populism, and anti-establishment politics in East Central Europe. SAIS Review, 17 (1), pp.49-62.

Webb, P. (2002) Introduction. Political Parties in Advanced Industrial Democracies. In: Political Parties in Advanced Industrial Democracies. pp.1-15. 